\title{
An Analysis on Price Dispersion in Online Retail Market Based on the Different of the Product Levels
}

\author{
CHEN Xiang-Bing, XIAO Kai
}

School of Economics and Management, Beijing University of Posts and Telecommunications, BeiJing, China School of Management, Wuhan University of Science and Technology, WuHan, China

\begin{abstract}
This paper cares about the online price dispersion and analyses the online retail commodity as a complex. This paper analyses the attributes of the product layer of the online retail commodity and the characters of the online customers, and divided the online payment into two parts: the payment of the core value and the willingness of the added-value payment. And then this paper explains the online price dispersion by the attributes of online retail commodity's dimension which affect the online customers directly.
\end{abstract}

Index Terms: price dispersion; online retail commodity; product levels

(C) 2012 Published by MECS Publisher. Selection and/or peer review under responsibility of the Research Association of Modern Education and Computer Science.

\section{Introduction}

Price dispersion is defined as the distribution of prices (such as range and standard deviation) of an item with the same measured characteristics across sellers of the item at a given point in time. Price dispersion is important from the perspectives of consumers, sellers, and the market as a whole. For consumers, price dispersion characterizes the alternative offerings in the market and affects search and purchase behavior. For sellers, it reflects the pricing strategy of competitors and their interactions. For the market, it is an important measure of information efficiency. This paper tries to explain the price dispersion by the product levels which could make the online retail commodity different.

\section{Related literature and online price dispersion}

Since the publication of Stigler's article on the Economics of Information, there is strong theoretical and empirical evidence that much (and in some markets, most) of the observed dispersion stems from information costs------consumers' costs of acquiring information about firms, and/or firms' costs of transmitting information 
to consumers. But in the online market which search cost will be lower than traditional market, price dispersion is persistent exist. The earliest empirical research on online price dispersion was conducted by Bailey (1998), who examined whether the Internet market is more efficient than the traditional market. Bailey found that price dispersion among e-tailers was at least as great as that among the traditional retailers. This finding is contrary to the expectation that online markets are more frictionless due to more intensive consumer search. In a related study, Brynjolfsson and Smith (2000) examined prices for a matched set of 20 books and 20 CDs sold through 41 online and off-line retail outlets. They found that online price dispersion was no narrower than off-line price dispersion. Lee and Gosain (2002) also found that the average of percentage price difference (price range deflated by average price) was no smaller online than it was off-line.

Why does online price dispersion exist? Many researchers have attempted to understand why it exists. Lynch and Ariely (2000) explained that richer non-price information leads to lower consumer price sensitivity and wider range of prices. They showed that, with greater product information online, wine shoppers become more price sensitive when different web sites carry the same wine, but become less price sensitive when different web sites carry unique wine. Chen and Hitt (2003) present an analytical model linking price dispersion to consumer awareness and sensitivity to retailer name. They showed that when consumers are sensitive (but not too sensitive) to retailers' brand names and/or not all consumers are fully aware of all available retailers and prices, retailers play asymmetric mixed strategy by randomizing their prices so that a better-known retailer has a higher price on average than a lesser-known retailer, but a lower price on some products and/or some of the time. Pan, Ratchford, and Shankar (2002) specifically examined whether online price dispersion could be explained by differences in e-tailer service quality. They identified four service factors (reliability, shopping convenience, product information, and shipping and handling) and an additional factor of e-tailer pricing policy. They found that better service often relates to lower prices and the dispersion of service quality adjusted price is only slightly smaller than that of the unadjusted price. Zhao Dongmei(2005) indicated that the market characteristics of product are the main reason of price dispersion and the heterogeneity in the services offered by e-tailers is only responsible for a limited portion of variation in the e-tailer prices and that the drivers of e-tailers price are different across the clusters.

Online price dispersion is a comprehensive reflection of the structure of online business market, the cost of online transaction, the searcher cost of online customers and the strategy of online retailers. Following the existing researches, this paper wants to clarify the relationship between the online service and the willingness of payment, and tries to explain that the online product different and the different of online customers' willing payment will result in online price dispersion.

\section{Online consumers' demand characteristics and the product levels of online retail commodity}

With the development of the Internet and e-commerce, the characteristics of online customers are diversification. The mainly feature of online customers' demand characteristics are significant, such as personalized needs, consumption initiative, the pursuit of shopping convenience and shopping fun. Online customers care not only the retail commodity but also incidental service of retail commodities. According to China Internet Information Center (CNNIC) survey, during the year of 2009, pay convenience (74.5\%), website search convenience $(73.6 \%)$, web response speed $(72.2 \%)$ and useful information $(71.7 \%)$ are the four satisfaction higher factors which online shopping customers care for. And the mainly four dissatisfaction factors are respectively commodity quality guarantee (50.9\%), after-sale security (51.8\%), protection of payment information (51.8\%) and after-sale service quality (55.5\%). Pan Yu, Zhang Xing, Gao Li(2010) also propose a purchasing intention influence model variances. They use structural equation model to explore the influences of online stores' brand image, sales management, services, technology security, and consumers' disposition to trust on consumers' trust and perceived risk, as well as their effect on purchasing intention. 
Table 1. five levels of online retail commodity

\begin{tabular}{|c|c|c|}
\hline $\begin{array}{c}\text { Product } \\
\text { Level }\end{array}$ & $\begin{array}{c}\text { Representationa } \\
\text { I Meaning } \\
\end{array}$ & Description \\
\hline The first & core product & $\begin{array}{l}\text { The core product stands at the center } \\
\text { of the total product. It consists of the } \\
\text { core, problem-solving benefits that } \\
\text { online consumers seek when they buy a } \\
\text { product or service. }\end{array}$ \\
\hline $\begin{array}{l}\text { The } \\
\text { second }\end{array}$ & actual product & $\begin{array}{l}\text { The actual product is around the core } \\
\text { product. Actual products may have as } \\
\text { many as five characteristics: website } \\
\text { operation management, a brand name, } \\
\text { logistics, after-sales service, and service } \\
\text { quality level. }\end{array}$ \\
\hline $\begin{array}{l}\text { The } \\
\text { third }\end{array}$ & expected product & $\begin{array}{l}\text { The expected product may be the } \\
\text { result of the online consumers' } \\
\text { expectation in the purchase process. It } \\
\text { should include the comment of other } \\
\text { online consumers, the relative } \\
\text { information of the commodity and } \\
\text { related product, and so on. }\end{array}$ \\
\hline $\begin{array}{l}\text { The } \\
\text { fourth }\end{array}$ & $\begin{array}{l}\text { augmented } \\
\text { product }\end{array}$ & $\begin{array}{l}\text { The augmented product is to offer } \\
\text { additional consumer services and } \\
\text { benefits. It may have many features: } \\
\text { insurance of commodity quality, } \\
\text { guarantee of online transaction, perfect } \\
\text { after-sale service, and so on. }\end{array}$ \\
\hline The fifth & potential product & $\begin{array}{l}\text { Potential product is a kind of value- } \\
\text { added services which could satisfy } \\
\text { customer potential requirements. It } \\
\text { mainly consists of website access speed, } \\
\text { abundance of online retail commodities, } \\
\text { shopping experience, communication } \\
\text { between online customers, and so on. }\end{array}$ \\
\hline
\end{tabular}

Online customers need not only the commodity but also the online service, so it is improper to separate the incidental service from the online retail commodities. From the angle of customers, online retail commodity should be regarded as a compound product concept. According to the theory of Philip Kotler's product levels, online retail commodity could be separated into five product levels: core product, actual product, expected product, augmented product, potential product (See Table 1).

\section{Product differentiations and Price dispersion}

There are many researches on the product differentiation, such as the address approach (the circular model and the linear city model) and non-address approach (Cournot model and Bertrand model). And it is generally considered that price dispersion is expansive when there is product differentiation. So product differentiation is an important means for the corporate to form market forces. There are three kinds of product differentiations: horizontal differentiation, vertical differentiation and informational differentiation. Horizontal differentiation is caused by the customers' different preference. That means the difference of product is due to consumers because they don't think they are the same. Vertical differentiation is caused by the product quality. When there are significant differences quality between the products and the price of the products are the same, the customers consistently prefer to high quality product. Informational differentiation is caused by the incomplete information. 
Based on the analysis of product differentiation and online retail commodity's product levels, we can see that the differences in consumer preferences and information will make consumers to think that online retail commodities are different products even though they are same matters. When there is a change on the factor of online commodity's product levels, the online commodity will change into another commodity, through the core product is the same. The differences in product will lead to the differences in transaction prices. According to the analysis of online consumers' demand characteristics: online customer need not only the commodity but also the online service, online commodity price can be separated into two parts: the cost of core benefit and the willingness payment for online retail value-added services.

The cost of core benefit mainly includes the cost of core product and actual product, which includes the cost of retail goods manufacture, the cost of logistics and informational service, the fee of website operation, and so on. The cost of core benefit is closely related to online retail commodities commercial properties, and it is the cost of operation and management. The differences of the core benefit cost mainly come from the difference of website operation's efficiency. So it is easy to lead to a vicious price competition based on the cost of core benefit.

The willingness payment for online retail value-added services are around the shopping process, which includes the payment for commodity information provided (the information communications between customers and retailers), insurance of online sale and convenience shopping experience. So it mainly includes expected product, augmented product and potential product. Conversed to the core benefit cost, the willingness payment for online retail value-added services is oriented by customers' need which concern about the online retail service quality. And the willingness payment is more variable and competitive. If online retailers want to complete on the value-added services, the different of online price will manifest itself as a non-price competition.

From the customer perspective, the price which online customers have to pay includes the cost of core benefit and the willingness payment for online retail value-added services. Fig. 1 shows that the change of the cost of core benefit and the willingness payment for online retail value-added services will make the online price changes.

Relevant literature also supports this analysis. Pan, Ratchford and Shankar (2002) showed that multichannel retailers have a higher price in equilibrium, when they have sufficiently lower transaction cost than pure online retailers. This is because they provide better pick-up and return service, more convenient product inspection, and greater consumer trust. Chen and Hitt (2003) showed that when consumers are sensitive (but not too sensitive) to retailers' brand names and not all consumers are fully aware of all available retailers and prices, retailers play asymmetric mixed strategy by randomizing their prices so that a better-known retailer has a higher price on average than a lesser-known retailer, but a lower price on some products and/or some of the time. The random pricing behavior produces online price dispersion. They also showed that an unbranded retailer has a weak incentive to improve consumer awareness even if the cost is zero, because that will increase price competition.

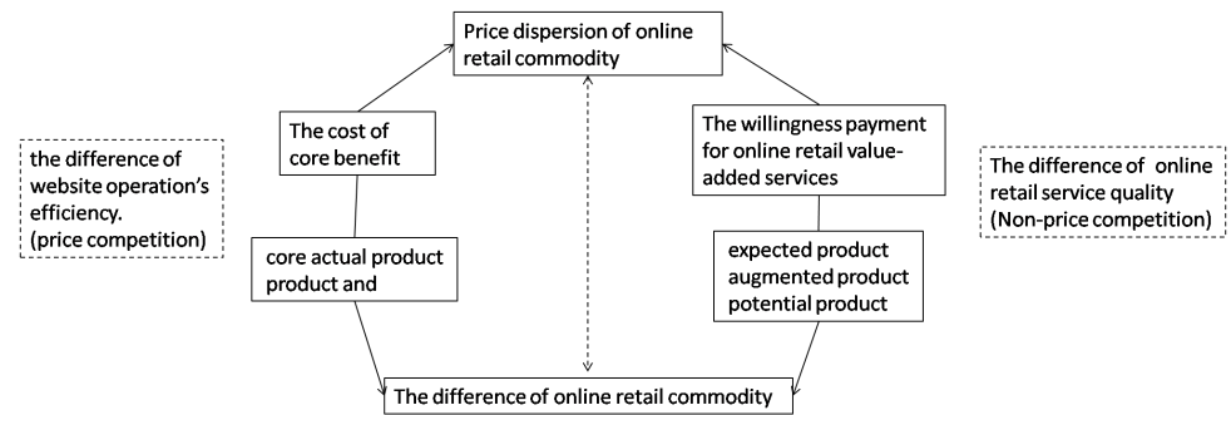

Fig. 1. Price dispersion and the difference of online retail commodity 


\section{Conclusion}

There are many factors that could affect online retail price such as retailer's reputation, online retailer's brand, after-sale services and online consumers' attitudes to the services. If we consider the online retail commodity as a complex whole, it will help us to understand online price dispersion. The difference of online retail commodity's product level will cause differentiation price. From the analysis of online product levels, we can see that online retails should avoid vicious price completion which will decrease retailers' operational efficiency. Online retailers should improve their service quality which could satisfy online customers' need, they should provide characteristic service and make customers enjoy the process of online shopping.

Although this paper explains online price dispersion by the analysis of product levels, we can't identify and estimate the effects of product levels, and we have no direct evidence to measure the willingness. All of these are the limitations of this paper. So using the survey data to measure and analyze will be the future research of this paper.

\section{References}

[1] George J.Stigler, The economics of information. Journal of Political Economy, Vol. 69, pp. 213-2251, March 1961.

[2] Pan, X., Ratchford, B.T., \& Shankar, V, Price dispersion on the internet: a review and directions for future research. Journal of interactinve marketing, Vol. 18, pp. 116-135, April 2004.

[3] Brynjolfsson, E., and Smith, M., Frictionless Commerce? A Comparison of Internet and Conventional. Retailers. Management Science, Vol. 46, pp. 563-585, April 2000.

[4] Lee, Z.,\&Gosain, S., A Longitudinal Price Comparison for Music CDs in Electronics and Brick-andMortar Markets. Pricing Strategies in Emergent Electronic Commerce. Journal of Business Strategies, Vol. 19, pp. 55-71, January 2002.

[5] Lynch, J., \& Ariely, D., Wine Online: Search Costs Affect Competition on Price, Quality, and Distribution. Marketing Science, Vol. 19, pp. 83-103, January 2000.

[6] Chen, P.Y., \& Hitt, L.M., "Understanding Price Dispersion in Internet-Enabled Markets (Working Paper)," unpubished.

[7] Pan Yu, Zhang Xing,Gao Li, Research on the Determinants of Purchasing Intertion in Online Shopping-From the perspectinv of Trust and Perceived Risk. China Industrial Economics, Vol. 268, pp. 115-124, July 2010 (In Chinese). 